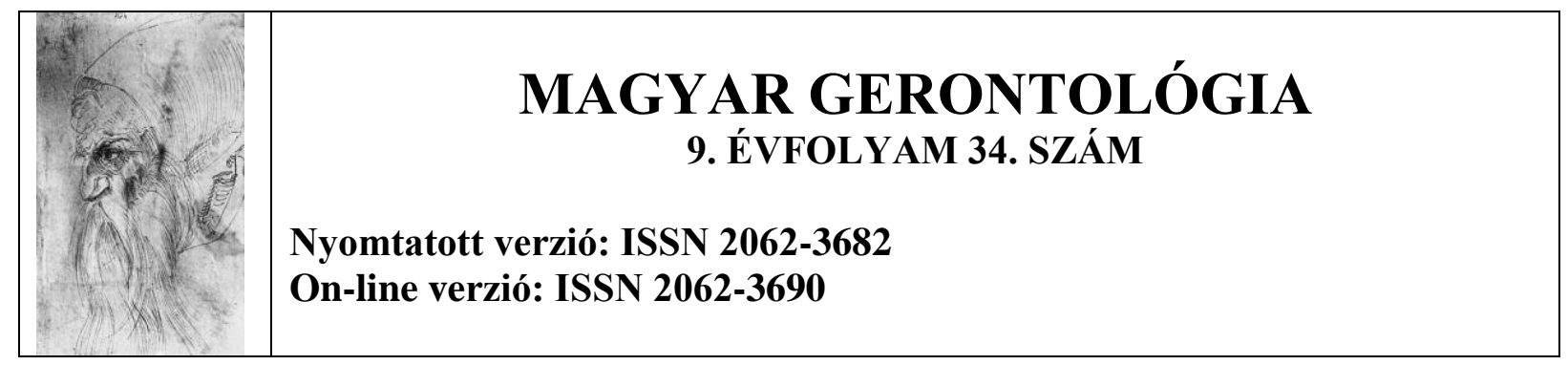

\title{
Intézményen belüli szakápolás a Nyíregyházi Szociális Gondozási Központ idősek otthonában ${ }^{2}$
}

\author{
Szilvásiné Bojda Márta
}

Kulcsszavak: szakápolás, idősek, szociális ellátó rendszer

\section{Összefoglalás}

Az integrált intézményként müködő Nyíregyházi Szociális Gondozási Központ két telephelyen, 63 férőhellyel müködteti Idősek Bentlakásos Intézményét.

Az ellátottak átlagéletkora 85 év. A mindennapi gondozásuk, ápolásuk egyre összetettebb feladat, melyek egy része kórházi ellátást igényel. Tapasztalataink szerint az idős, estlegesen a betegségtől legyengült ellátottak kórházba szállítása, az ott, várakozással és ellátással töltött idő még inkább megviseli a szervezetüket, pszichés állapotukat.

Az ellátottak és hozzátartozóik igényeihez igazodva a két telephelyen kiegészítő tevékenységként, egészségügyi szolgáltatást vezettünk be, mely kifejezetten a szociális ellátórendszerre épül, és legalizálja az intézményen belüli egészségügyi ellátást.

\section{Bevezetés}

Szeretném bemutatni Önöknek, hogyan találkozik és olvad össze a kor elvárásainak és a „keresletnek” megfelelően, a szociális ellátás és az egészségügyi szolgáltatás. Egy emberöltővel ezelőtt, a család a szülőket, nagyszülőket halálukig gondozta, ápolta. Az „öregotthonokba beadni” az idős, ellátásra szoruló szülőket, stigmának számított.

A XX. század közepéig az intézményi idős ellátás fő célja, a hozzátartozó nélküli idős emberek ápolása és gondozása volt. Az 1960-70-es években változás indult el ez idősekkel való állami gondoskodás terén. Idős nappali ellátások (napközi otthonok) alakultak, határozott célokkal. Megjelent az egészség-megőrzés és az orvosi felügyelet biztosítása, gyógyszerelés,

\footnotetext{
${ }^{2}$ Elhangzott a Nyíregyházi Gerontológiai Napok 2016. évi konferenciáján
} 
később programok szervezése - a mentális egészség megőrzése az állam által biztosított keretek között. Alig múlt el néhány év, a társadalom struktúrája átalakult, egyre nő az idős, nyugdíjas korú lakosok száma. A korosztályok eltolódásának eredménye, hogy egyre több az olyan 65 év feletti idős ember, akiknek hozzátartozói, aktív munkavállalói státuszban élik az életüket.

\section{- Van e ma lehetőség a gondoskodásra szoruló szülők ápolására, gondozására?}

A nyugdíjas szülök addig, amíg egészségesek és képesek gondoskodni magukról, nem jelentenek különösebb terhet a családok számára. Abban a pillanatban, ha valamelyik szülő egyedül marad, vagy komolyan megbetegszik, megváltozik a családok élete, életritmusa, eltolódnak a hangsúlyok.

- Mit tehet egy aktív korban lévö dolgozó ember, ha gondoskodni kell a szüleiröl, különösen, ha 24 órában igényelne felügyeletet, gondoskodást?

Magyarország lakossága szerencsésnek mondható, hiszen részletesen kidolgozott az idős, megromlott egészségi állapotú emberek kórházon kívüli ellátása, szakápolása, bár az utóbbi két évben folyamatos átalakuláson megy át az idősek szociális ellátó rendszere. A szociális alapszolgáltatások, a házi segítségnyújtás, a jelzőrendszeres házi segítségnyújtás, biztonságos gondoskodást nyújt az idős emberek számára saját lakókörnyezetükben, így a hozzátartozók is biztonságban tudhatják szeretteiket. Ha az idős ember kora, vagy egészségi állapota miatt 24 órás felügyeletre, gondozásra - ápolásra szorul, bentlakásos intézményben, idősek otthonában kerülhet elhelyezésre. Az idős otthon lakói számára 24 órában biztosít teljes körü ellátást, gondoskodást.

Egy 2011-ben készült tanulmány szerint ma Magyarországon az idősellátás területén a bentlakásos intézményekben az engedélyezett férőhelyek száma 850 intézményben 57017 db. A férőhely kihasználtság 96,3\%-os, a lakók mintegy 8\%-a 65 év alatti. A várakozók száma 10364 fö. Az igény a tartós bentlakásos elhelyezés iránt nagyon magas, a müködő férőhelyek számához viszonyítva $25 \%$ a várakozók aránya. ${ }^{3}$

\section{A Nyíregyházi Szociális Gondozási Központ}

A Nyíregyházi Szociális Gondozási Központ integrált intézményként Nyíregyháza, Nyírpazony közigazgatási területén biztosít szociális ellátást, nyolc alapszolgáltatás és egy

\footnotetext{
${ }^{3}$ Területi Szakértői Csoport Bentlakásos Idősellátás Nemzeti Család- és Szociálpolitikai Intézet TÁMOP 5.4.1. Szakértők: Dr. Egervári Ágnes Czibere Károly Panker Mihály
} 
szakosított ellátás formájában. Ellátottjaink idős és fogyatékkal élő felnőttek, illetve kezelt, egyensúlyban lévő pszichiátriai betegek.

Jelenleg 22 telephelyen 200 szakképzett munkavállaló, közel 2000 ellátottról gondoskodik. Szakosított ellátás keretében „Családias elhelyezést biztosító Idősek Otthona” -t müködtetünk Nyíregyháza belvárosában, illetve a város külterületén, Oroson. Csendes, nyugodt környezetben összesen 63 féröhelyet biztosítunk idős emberek számára, életvitelszerű bentlakással. Lakóink számára koruknak és egészségi állapotuknak megfelelő, korszerü fizikai, egészségügyi és mentálhigiénés ellátást biztosítunk. Rendszeres háziorvosi felügyelet mellett élményszerü ellátást nyújtunk.

Mindennapi tapasztalataink azonban az jelezték, hogy az otthonokba jelentkező nyugdíjasok egyre idősebbek és egyre labilisabb egészségi állapotúak. (Az elhelyezésre várakozók száma jelenleg 89 fő.) 2010-től saját adatainkat áttekintve és összesítve azt láttuk, hogy az elhalálozások gyakorisága jelentősen megnőtt, mely az életkor előrehaladtával egyenes arányban áll.

Azt is láttuk, hogy az ellátottak nagy része évente több alkalommal is kórházi ellátásra szorul, sokszor olyan 1-2 napos ellátásra kerül sor, mely szakápolás keretében elvégezhető. „,Ma Magyarországon az idősellátás két terület: az egészségügy és a szociális ellátórendszer kompetenciájába tartozik. A hatályos szabályozásban nagyon sok a két szféra közötti átfedés, párhuzamosság. A tartalmilag hasonló ápolási-gondozási feladatok jelenleg két eltérő ágazati logikába ágyazottan, eltérő minimumfeltételek, protokollok, hozzáférési rend és finanszírozási filozófia szerint valósulnak meg." 4

A két rendszert párhuzamosságok jellemzik és a kapacitásbefogadási rendszer sem összehangolt az egészségügyi és szociális rendszerben. „Mindez a finanszírozás vonatkozásában is felvet bizonyos kérdéseket, mivel az intézményekben elvégzett egészségügyi tevékenységek (szakápolás) finanszírozásába az OEP nem kapcsolódik be. ",

A Nyíregyházi Szociális Gondozási Központ valamennyi munkatársa szakképzett gondozó-ápoló, illetve szociális gondozó, mégsem végezhették el a szakápolási tevékenységet, mert a bentlakásos intézménynek nincs külön egészségügyi szakápolási tevékenységre szóló működési engedélye. Az idős emberek gyakran, a rövid kórházi

\footnotetext{
${ }^{4}$ Területi Szakértői Csoport Bentlakásos Idősellátás Nemzeti Család- és Szociálpolitikai Intézet TÁMOP 5.4.1. Szakértők: Dr. Egervári Ágnes Czibere Károly Panker Mihály

${ }^{5}$ Területi Szakértői Csoport Bentlakásos Idősellátás Nemzeti Család- és Szociálpolitikai Intézet TÁMOP 5.4.1. Szakértők: Dr. Egervári Ágnes Czibere Károly Panker Mihály
} 
tartózkodás után is elesett állapotban, lelkileg is meggyötörten kerülnek vissza az otthonba. Ezeket látva, összegezve döntött az intézmény vezetése úgy, hogy kiegészítő tevékenységként bevezetjük az intézményi szakápolást.

Az intézményi szakápolás a gondozás - ápolást kiegészítő egészségügyi szolgáltatás, a szakápolás körébe tartozó tevékenység, mely a rövid kórházi tartózkodásokat igénylő ellátásokat váltja ki, rövidíti le. Célja az idős ember állapotának, életminőségének javítása, az egészség megőrzése illetve helyreállítása, a szenvedés enyhítése.

Az ápolás, speciális felkészülést és ismereteket kíván az ápoló személyzettől. Az egészségügyi ellátást a bentlakásos intézmény orvosa rendeli el. A tevékenységeket a helyi, egészségügyi szakképesítéssel rendelkező ápolók végzik, a szakápolási protokollnak megfelelően.

Az Intézményi Szakmai Programnak része a szakápolási protokoll, melynek kötelező mellékletében pontosan meghatároztuk az egyes szakirányú tevékenységeket. Az intézményen belüli szakápolást az alábbi törvények, rendeletek szabályozzák. A személyi és tárgyi feltételek biztosításán túl a szolgáltatás, csak egészségügyi müködési engedéllyel végezhető.

A 1997. évi CLIV.törvény az egészségügyről pontosan meghatározza, hogy melyek azok az egészségügyi tevékenységek, melyeket el kell látni, milyen szakembereket milyen feltételekkel kell alkalmazni.

Az 1/2000 SZCSM rendelet meghatározza, hogy milyen egészségügyi tevékenységeket kell elvégezni az idősotthonokban és az ellátáshoz milyen minimumfeltételekkel kell rendelkezni. Az elvégezhető tevékenységeket személyi és tárgyi feltételek határozzák meg

60/2003. (X.20.) ESZCSM rendelet az egészségügyi szolgáltatások nyújtásához szükséges szakmai minimumfeltételekről 
A szakápolás bevezetéséhez szükséges változtatások

\begin{tabular}{|l|l|}
\hline \multicolumn{1}{|c|}{ Idősek otthona müködési feltételei } & Szakápolás minimum feltételei \\
\hline $\begin{array}{l}\text { Szociális és Gyámhivatal (ma már } \\
\text { Kormányhivatal) müködési engedély }\end{array}$ & Egészségügyi müködési engedély \\
\hline Szakmai program - Szociális Tv. szerint & $\begin{array}{l}\text { Szakmai program egészségügyi protokollal } \\
\text { kiegészítve }\end{array}$ \\
\hline Személyi feltételek - Szociális.Tv. szerint & $\begin{array}{l}\text { Személyi feltételek egészségügyi protokollal } \\
\text { kiegészítve }\end{array}$ \\
\hline $\begin{array}{l}\text { Tárgyi feltételek - alap egészségügyi } \\
\text { ellátáshoz }\end{array}$ & Tárgyi feltételek szakápoláshoz \\
\hline Azz Intezmén
\end{tabular}

Az Intézményben az egészségügyi ellátás, ápolás szerves részét képezi az itt élő idősek intézeti keretek között végzett gondozásának. Az ápolási, gondozási tevékenység az ápolási terv alapján segít azon tevékenységek elvégzésében, amelyek hozzájárulnak az ellátott jó egészségéhez, gyógyulásához, rehabilitációjához. Az ápolási tevékenységről ápolási dokumentációt vezetünk, amely része a személyi dokumentációnak.

A szakápolási tevékenységet orvosi elrendelés, előzetes szükségletfelmérés, és tervezés alapján, egészségügyi szakdolgozók végzik. Az ápolás önálló tevékenység, mely a szakápolók részéről nagyfokú együttmüködő képességet, határozottságot és a kompetencia határok maximális ismeretét igényli.

A szakápolás során folyamatosan biztosítani kell a beteg pszichés támogatását, étkezési és életmód tanácsadását, különösen azon tevékenységek megtanítását kell szorgalmazni, amelyeket maga az idős ember tehet az egészsége megtartásáért, helyreállításáért vagy állapot romlásának megakadályozásáért. Biztosítani szükséges a rendszeres kommunikációt a kezelőorvossal és más, az ellátásában résztvevő személyekkel.

A szakápolási feladat a szociális ellátásra épül, melyben az orvosi tevékenységen belüli konzultáció súlyozottá válik.

\section{A munkában résztvevö szakemberek}

- OKJ szakápoló, diplomás ápoló

- Dietetikus

- Gyógytornász

- Mentálhigiénikus 


\section{Elvégezhetö szakápolási tevékenységek}

- higiénés kézfertőtlenítés

- intravénás folyadék- és elektrolit pótláshoz, parenterális gyógyszer beadásához kapcsolódó szakápolási feladatok

- vér- és testváladékok vétele laboratóriumi vizsgálat céljából

- intramuszkuláris injekció

- a légutak szájon át történő leszívásához kapcsolódó szakápolási feladatok

- oxigénterápia

- trachea kanül tisztításához és betét cseréjéhez kapcsolódó szakápolási feladatok

- állandó katéter cseréjéhez vagy rendszeres katéterezéshez kapcsolódó szakápolási feladatok

- hólyagöblítéshez kapcsolódó szakápolási feladatok

- gyógyászati segédeszközök használatához kapcsolódó szakápolási feladatok

- krónikus fájdalom csillapítása

- decubitus felmérés és prevenció

- decubitus kezelése

- a beteg elökészítése eszközös vizsgálatokhoz

- perfúzor használatához kapcsolódó szakápolási feladatok

- szondán át történő tápláláshoz és folyadékbevitelhez kapcsolódó szakápolási tevékenységek végzése

- EKG készítéshez kapcsolódó szakápolási feladatok

- a fokozottan ellenőrzött szerek tárolásáról, nyilvántartásáról

- sürgősségi ellátás

- a haldokló beteg ellátása

A tapasztalat azt igazolja, hogy az orvosi gyógyító és megelőző munka terén, hosszú távon akkor érhető el a legjobb eredmény, ha nem csak a betegség testi tüneteivel, hanem a teljes személyiséggel foglalkozunk, ezért nagyon fontos az ellátotti edukáció, a folyamatos mentálhigiénés tevékenység.

Lakóink átlag-életkora 80 év fölött van. Évek óta vannak 100 életévet betöltött, jó egészségi állapotú ellátottjaink.

\section{Célként tüztük ki az idősotthoni ellátás során}

- Az idősek életminőségének megtartását, javítását

- A szolgáltatások összehangolását és összekapcsolását 
- Az élményszerü ellátást

- Az egyéni bánásmód kialakítása

- Az idősek igényeinek, érzékenységének figyelembe vételét

\section{Összegzés}

Az idősellátás jövője nehezen jelezhető előre, az azonban tisztán látható, hogy folyamatos az átalakulás. A szociális rendszer, benne az idősellátás átalakítása elkezdődött, és folyamatosan halad elöre. Bizonyos tendenciák előrevetítettek, mint a népesség várható élettartamnak növekedése, a termékenységi ráta stagnálása, esetleges csökkenése, a népességen belül az idősek és a nagyon idősek arányának növekedése, a morbiditási kockázatok korcsoportonkénti jelentős növekedése.

A fentiekből olyan szakellátási jövő kalkulálható, amely magasan professzionalizálódott, mind a feladatellátás, mind a szakemberek tekintetében. A fejlődés útját belső innováció, a belső szakmafejlesztés, a szemléletváltás határozza meg. Az egységes sztenderdek és protokollok egyértelmüvé teszik azokat a normákat, melyek mentén megújíthatunk egy emberközpontú ellátást, mely a kor követelményeinek is megfelel. Bízom abban, hogy idős lakóink utolsó életszakaszában sikerül megőriznünk az emberi méltóságukat azzal, hogy nyugodt, kiegyensúlyozott, biztonságos környezetet biztosítunk számukra nap mint nap, mellyel ők is elégedettek. Elégedettek és nyugodtak az ellátottak hozzátartozói is, mely számunkra sem közömbös.

Intézményünkben „reményeim szerint” emberközpontú, kiegyensúlyozott szolgáltatást biztosítunk, melyben nyugodt és kiegyensúlyozott a dolgozó is, aki nap mint nap az idős emberek között végzi a munkáját.

\section{Irodalomjegyzék}

Területi Szakértői Csoport Bentlakásos Idősellátás Nemzeti Család- és Szociálpolitikai Intézet TÁMOP 5.4.1. Szakértők: Dr. Egervári Ágnes Czibere Károly Panker Mihály

Szakápolási protokollok / Sciller Natália, Katonáné Pócz Katalin, Tompos Tamás, Katona Józsefné, Dr. Kádas Zsófia

\section{Szerzö:}

Szilvásiné Bojda Márta

Igazgató

Nyíregyházi Szociális Gondozási Központ 